\title{
Pelatihan Berpikir Positif untuk Meningkatkan Penerimaan Diri Survivor Bipolar di Yogyakarta
}

\author{
Andhita Dyorita Khoiryasdien \\ Program Studi S1 Psikologi, Universitas 'Aisyiyah Yogyakarta \\ dyorita.kh@unisayogya.ac.id \\ Annisa Warastri \\ Program Studi S1 Psikologi, Universitas 'Aisyiyah Yogyakarta \\ annisawarastri@unisayoagya.ac.id
}

\begin{abstract}
This research is about mood disorders (Bipolar) in the city of Yogyakarta. Yogyakarta has a place for bipolar survivors namely BCI (Bipolar Care Indonesia knot Jogja). Some therapeutic efforts that have been made show that the effectiveness of therapy depends on self-acceptance of ODB (people with bipolar disorder). If $O D B$ still cannot accept that he is diagnosed with bipolar disorder, it will be difficult to be able to accept various types of therapy both psychotherapy and pharmacism. The subjects involved in this study were 10 people. People with $O D B$ are given positive thinking training that is expected to provide a more positive change towards self-acceptance. This research uses a quasi-experimental method. The design used is one group pretest-posttest design. Positive thinking training was conducted six times. Based on the results of the study obtained an increase in positive thinking scores from pretest to posttest. In other words, Positive Thinking Training is effective for increasing self-acceptance of $O D B$.
\end{abstract}

Keywords: self-acceptance; positive thinking; people with bipolar.

\begin{abstract}
Abstrak
Penelitian ini membahas tentang gangguan mood (Bipolar) di Kota Yogyakarta. Yogyakarta mempunyai wadah bagi para survivor bipolar yaitu BCI (Bipolar Care Indonesia simpul Jogja). Beberapa upaya terapi yang telah dilakukan menunjukan bahwa keefektifan terapi tergantung pada penerimaan diri $O D B$ (orang dengan bipolar). Apabila $O D B$ masih belum bisa menerima bahwa dirinya terdiagnosa bipolar, maka akan sulit untuk bisa menerima berbagai jenis terapi baik psikoterapi maupun farmaka. Subjek yang terlibat dalam penelitian ini berjumlah 10 orang. $O D B$ diberikan pelatihan berpikir positif yang diharapkan dapat memberikan perubahan kearah yang lebih positif terhadap penerimaan diri. Penelitian ini menggunakan metode kuasi-eksperimen. Desain yang digunakan adalah one group pretest-posttest design. Pelatihan berpikir positif dilakukan sebanyak enam kali pertemuan. Berdasarkan hasil penelitian diperoleh adanya peningkatan skor berpikir positif dari pretest ke posttest. Dengan kata lain, Pelatihan Berpikir Positif efektif untuk meningkatkan penerimaan diri $O D B$
\end{abstract}

Kata Kunci: penerimaan diri; berpikir positif; orang dengan bipolar. 


\section{Pendahuluan}

Gangguan Bipolar atau yang biasa disebut dengan Gangguan Mood mempunyai dua fase yaitu fase depresi dan fase mania. Fase depresi berpusat pada emosi dimana emosi seseorang berada dalam kondisi kesedihan yang sangat ekstrim, sedangkan serta kondisi sangat senang secara berlebihan dan mudah terstimulus atau yang biasa disebut dengan kondisi mania. Iis Inayati, wakil dekan I Fakultas Kedokteran Unjani menyampaikan bahwa Word Health Organization (WHO) mengestimasikan beban penyakit akibat depresi di tahun 2020 berada di peringkat ke-2 dan di tahun 2030 berada di peringkat ke-1 (Abdurahman, n.d.,2017)

Baik kondisi mania maupun depresi tentu sangat membahayakan kondisi ODB karena saat kondisi mania, seseorang bisa nekat melakukan hal-hal ekstrim sedangkan pada kondisi depresi seorang ODB mempunyai faktor resiko bunuh diri yang cukup tinggi (Safira, 2014)

Di Yogyakarta sendiri, cukup banyak orang yang sudah terdiagnosis gangguan bipolar, hanya saja belum pernah dilakukan survey sehingga belum diketahui secara pasti jumlah ODB di Yogyakarta. Meskipun begitu, Yogyakarta mempunyai komunitas khusus untuk orang yang mengalami gangguan bipolar yaitu Bipolar Care Indonesia atau yang biasa disingkat dengan BCI simpul Jogja. Komunitas ini baru saja terbentuk kurang lebih selama dua tahun setelah terbentuknya BCI Pusat di Jakarta. Saat ini tercatat ada 254 anggota yang tergabung dalam grup media sosial facebook, sedangkan ada sekitar 60 ODB (Orang Dengan Bipolar) yang aktif saling berinterkasi melalui grup Whats up.

Berdasarkan survey yang dilakukan di lapangan, menunjukan bahwa sebagian besar ODB belum bisa menerima kenyataan bahwa dirinya mengalami gangguan Bipolar. Beberapa anggota komunitas bipolar mengaku bahwa mereka sering bertanya-tanya mengapa harus dirinya yang mengalami bipolar, merasa dirinya baik-baik saja tanpa perlu pengobatan, masih denial dengan kondisi diri dan lain-lain sehingga terkadang ODB enggan untuk melakukan konsultasi dengan psikolog atau psikiater dengan rutin. 
Berdasarkan hasil wawancara dengan beberapa ODB, saat seseorang terdiagnosis ODB tentu dia akan merasa shock dan sulit untuk mempercayainya karena bisa dikatakan bahwa gangguan bipolar akan menetap pada diri seseorang selama hidupnya, terkecuali ODB rajin melakukan psikofarmaka dan psikoterapi. Menurut Psikiater RSA UGM, dr.Tika Prasetyawati., Sp.Kj (10/6/2017) saat seorang ODB sudah mau menerima dan melakukan pengobatan dengan baik, maka dosis obat pun bisa diturunkan,sedikit demi sedikit sesuai dengan kebutuhan pasien. Intensitas dalam melakukan Psikoterapi juga bisa dikurangi. Meskipun begitu, hal tersebut tidak menutup kemungkinan seorang ODB mengalami kekambuhan karena faktor tertentu

ODB yang masih denial tentu sangat mempengaruhi tindakannya dalam melakukan pengobatan. Hal ini sesuai dengan hasil wawancara yang sudah dilakukan pada beberapa ODB di komunitas BCI. Sebagian dari ODB mengaku bahwa dirinya belum bisa menerima bahwa dirinya terdiagnosis Gangguan Bipolar, hal tersebut membuat ODB enggan untuk rutin melakukan terapi ke psikolog atau psikiater dengan rutin. Beberapa responden yang lain juga mengatakan bahwa dirinya merasa tidak berharga, kadang merasa jijik dengan dirinya sendiri, masih merasa bingung dan heran dengan dirinya sendiri, merasa buruk dan rumit serta merasa tidak menyenangi dirinya sendiri. Hal tersebut tentu saja sangat mempengaruhi produktivitas dan kesejahteraan seorang ODB karena saat gangguan Bipolar tidak tertangani tentu saja akan mengarah pada hal-hal yang tidak diinginkan seperti resiko bunuh diri yang tinggi. Oleh karena itu, hal terpenting yang harus dilakukan adalah bagaimana membantu ODB untuk bisa mencintai dan menerima diri apa adanya sehingga akan menumbuhkan kesadaran untuk melakukan pengobatan. Sesuai dengan yang dikemukakan oleh Engelbertha (Indarini, 2017) pertama pasien harus menerima dulu, menerima bahwa dirinya mengalami gangguan bipolar. Karena dengan menerima, maka dia akan mau menerima bantuan baik dari medis ataupun orang lain. (E. Hurlock, 2014) menyebutkan bahwa salah satu faktor psikologis yang memberi kontribusi pada kesehatan mental individu adalah penerimaan diri. 
Oleh karena itu, diperlukan adanya suatu intervensi yang dapat meminimalisir afek negatif yang mengarah pada rendahnya penerimaan diri orang yang mengalami gangguan bipolar. Adapun alternatif treatment yang dapat diberikan untuk meningkatkan penerimaan diri adalah dengan memberikan Pelatihan Berpikir Positif.

(Rufaida, 2018) mengungkapkan bahwa dengan berpikir positif akan memunculkan: optimis, harapan positif, berbaik sangka (khusnudzan), mengambil hikmah (pelajaran) dari setiap peristiwa. Keadaan-keadaan optimis, berbaik sangka dan mengambil hikmah tersebut sebagai bentuk-bentuk respon terhadap berbagai keadaan, baik keadaan yang menyenangkan (baik) maupun yang tidak menyenangkan (buruk). Dengan demikian, individu yang berpikir positif akan segera menyudahi perasaan-perasaan kecewa, menyesal, diganti dengan upaya berbenah diri dengan menyadari posisi, peran, dan tanggung jawabnya sesuai dengan pilihan hidup dan keberadaannya di tengah lingkungannya

Berbeda dengan penelitian sebelumnya, dalam penelitian ini akan dilakukan uji modul pelatihan yang telah dimodifikasi oleh peneliti dan disesuaikan dengan dengan responden yaitu survivor bipolar. Menurut (Chatton, 2016) berpikir positif merupakan salah satu cara berpikir yang lebih baik menekankan pada hal-hal yang positif, baik terhadap diri sendiri, orang lain, maupun situasi yang dihadapi. Menurut Rufaida (2018) berpikir positif merupakan salah satu model pelatihan untuk melatih cara berpikir individu dengan memandang segala sesuatu hal dari sisi positifnya baik terhadap diri sendiri, orang lain, maupun situasi yang dihadapi. Meskipun pelatihan berpikir positif sudah banyak dilakukan, namun belum banyak penelitian yang secara khusus melihat efektifitas pelatihan berpikir positif untuk survivor bipolar dalam meningkatkan peneriman dirinya.

Peneliti menggunakan modul pelatihan berpikir positif yang disusun oleh Rufaida (2018) dan dimodifikasi oleh peneliti dengan menyesuaikan responden yaitu survivor bipolar. Pelatihan berpikir positif ini mengacu pada aspek-aspek berpikir positif menurut Albrecht (Rufaida, 2018) yang diintegrasikan dengan 
teori A-B-C Albert Ellis yang dikemas dalam bentuk sesi-sesi praktek Afirmasi Diri, Harapan yang Positif, Pernyataan yang Tidak Menilai serta Penyesuaian Diri terhadap Kenyataan. Pada tiap sesi praktek games tersebut akan dipraktekan teori A-B-C Ellis, sehingga survivor bipolar dapat mengalami sendiri secara langsung pikiran yang muncul dalam diri masing-masing indvidu atas terjadinya suatu peristiwa. Dampak tersebut antara lain, (A) yang dapat berdampak pada emosi serta perilaku individu (C). A adalah keberadaan suatu fakta, suatu peristiwa, tingkah laku atau sikap individu, B adalah keyakinan individu tentang $\mathrm{A}$, dan $\mathrm{C}$ yakni reaksi emosional (Corey, 2010)

\section{Penerimaan Diri}

(E. B. Hurlock, 1991) menjelaskan bahwa penerimaan diri adalah suatu keadaan ketika individu memiliki keyakinan akan karakteristik dirinya, serta mampu dan mau untuk hidup dengan keadaan tersebut. Dengan demikian, individu dengan penerimaan diri memiliki penilaian yang realistis tentang potensi yang dimilikinya yang dipadukan dengan penghargaan atas dirinya secara keseluruhan. Artinya individu ini memiliki kepastian akan kelebihankelebihannya dan tidak mencela kekurangan-kekurangan pada dirinya. Individu yang memiliki penerimaan diri mengetahui potensi yang dimilikinya dan dapat menerima kelemahannya.

Sejalan dengan Hurlock, Maslow (Alwisol, 2014) mengemukakan bahwa individu yang sehat akan menunjukan rasa hormat terhadap dirinya dan oranglain, menerima dirinya dengan keterbatasan, kelemahan, kerapuhan sehingga individu ini bebas dari rasa bersalah, malu dan rendah diri, juga dari kecemasan akan penilaian oranglain.

Follingstad (Nevid, 2007) mengemukakan bahwa saat seseorang tidak dapat menerima diri maka akan ada kecenderungan orang tersebut untuk menyalahkan diri sendiri, membenci diri, mempunyai pikiran negatif, tidak mempunyai kepercayaan diri, merasa tidak berdaya serta menarik diri dari lingkungan. Seseorang yang bisa dikatakan bisa menerima dirinya dijabarkan oleh Johnson (Rahmandani \& Subandi, 2010) adalah sebagai berikut : (1) Menerima diri sendiri apa adanya dan individu yang dapat menerima diri dapat melihat masa 
depan secara positif. Individu tidak hanya mengenal dirinya, dan juga menyadari kenyataan dirinya, (2) Tidak menolak diri sendiri apabila memiliki kelebihan dan kekurangan, (3) Memiliki keyakinan bahwa untuk mencintai diri sendiri, individu tidak harus dicintai dan dihargai oleh individu lain (4) Merasa berharga, sehingga individu tidak perlu merasa dirinya benar-benar sempurna (5) Memiliki keyakinan bahwa dia mampu untuk menghasilkan kerja yang berguna.

\section{Pelatihan Berpikir Positif}

Menurut (Macleod \& Moore, 2000) menyatakan bahwa terapi kognitif adalah mengenai berpikir secara realistis yang kemudian disebut sebagai berpikir positif atau dapat dikatakan bahwa berpikir positif adalah berpikir realistis dimana berpikir realistis merupakan bentuk dari terapi kognitif. (Santoso, 2011) pelatihan adalah proses pembelajaran yang lebih menekankan praktek daripada teori yang dilakukan seseorang atau kelompok dengan menggunakan pendekatan berbagai pembelajaran dan bertujuan meningkatkan kemampuan dalam satu atau beberapa jenis ketrampilan tertentu. Sedangkan Quilliam (2007) berpikir positif berarti berusaha menyadari masalah secara seimbang sehingga individu tetap termotivasi, mampu bertindak, dan merasa senang dengan tindakan tersebut. Selanjutnya, (Machmudati \& Diana, 2017) menjelaskan bahwa berpikir positif merupakan sikap mental yang melibatkan proses memasukkan pikiran-pikiran, kata-kata, dan gambaran-gambaran yang konstruktif (membangun) perkembangan pikiran. Sejalan dengan pemaparan sebelumnya, Chatton (2016) menjabarkan berpikir positif sebagai cara pandang seseorang dalam melihat suatu hal dari sisi positifnya atau mencari hal-hal positif dari setiap peristiwa sehingga mengarahkan seseorang untuk bertindak dan menghasilkan tindakan-tindakan yang positif.

Berdasarkan uraian diatas pelatihan berpikir positif adalah proses pembelajaran yang lebih menekankan praktek daripada teori mengenai cara pandang seseorang dalam melihat suatu hal dari sisi positifnya. Hal tersebut melibatkan proses memasukkan pikiran-pikiran, kata-kata, dan gambarangambaran yang membangun perkembangan pikiran, sehingga individu mampu bertindak positif dan tetap termotivasi. 
Penelitian ini diharapkan dapat memberikan manfaat antara lain menambah wawasan dan pemahaman mengenai pelatihan berpikir positif bagi ODB. Kedua, pelatihan berpikir positif ini bisa menjadi salah satu intervensi untuk menangani permasalahan individu yang mengalami gangguan bipolar. Ketiga, memperkaya hasil penelitian sebelumnya serta sebagai sebagai salah satu referensi bagi penelitian selanjutnya.

\section{Metode}

\section{Rancangan Penelitian}

Penelitian ini menggunakan metode kuasi-eksperimen. Desain yang digunakan adalah one group prestest-posstest design. Desain pada penelitian ini adalah sebagai berikut :

Tabel 1. Desain Penelitian

\begin{tabular}{rcc}
\hline Prestest & Intervensi & Posttest \\
\hline$Y_{1}$ & $X$ & $Y_{2}$
\end{tabular}

\section{Keterangan :}

Y1: Pengukuran Tingkat Penerimaan diri sebelum intervensi

$\mathrm{X}$ : Pemberian treatment berupa Pelatihan Berpikir Positif

Y2: Pengukuran Tingkat Penerimaan Diri

Secara keseluruhan proses uji coba modul Pelatihan Berpikir Positif pada Survivor Bipolar mencakup enam tujuh kali pertemuan. Pelatihan Berpikir Positif dilakukan sebanyak tiga kali pertemuan, dalam kurun waktu dua bulan selama empat jam di setiap pertemuan. Ada satu pertemuan di awal yang membahas tentang informed consent dan membangun rapport bersama komunitas BCI (Bipolar Care Indonesia Simpul Jogja). Kemudian dilanjutkan dengan dua pertemuan yang akan membahas tentang pengenalan dan komitmen responden penelitian dan pertemuan ke-5 yang akan diisi evaluasi pelaksanaan terapi dan post-test.

Pengukuran awal (pretest) tingkat penerimaan diri $O D B$ akan dilakukan di pertemuan pertama sebelum dilaksanakannya pelatihan. Sedangkan, untuk pengukuran akhir (posttest) tingkat penerimaan diri akan dilakukan pada pertemuan ke-6 setelah pelatihan diberikan. Untuk selanjutnya, pertemuan ke-7 
akan dilakukan follow-up. Hal ini dimaksudkan agar peserta dapat memahami perbedaan yang dialami setelah mengikuti pelatihan dan dapat mengevaluasi dirinya

Pelaksanaan Pelatihan Berpikir Positif ini akan dilakukan oleh trainer yaitu praktisi psikolog klinis yang sudah berpengalaman dalam menangani orang dengan gangguan bipolar (ODB) dan sudah berpengalaman dalam melakukan terapi serta pelatihan dalam bidang psikologi klinis.

\section{Penerimaan Diri}

Secara operasiona, seseorang yang bisa dikatakan bisa menerima dirinya dijabarkan oleh Johnson (Subandi \& Rachmadani, 2010) adalah orang yang dapat menerima diri sendiri apa adanya, tidak menolak diri sendiri apabila memiliki kelebihan dan kekurangan, memiliki keyakinan bahwa untuk mencintai diri sendiri, individu tidak harus dicintai dan dihargai oleh individu lain, merasa berharga, sehingga individu tidak perlu merasa dirinya benar-benar sempurna serta memiliki keyakinan bahwa dia mampu untuk menghasilkan kerja yang berguna.

\section{Pelatihan Berpikir Positif}

Pelatihan ini mengacu pada modul yang disusun oleh (Rufaida, 2018) dan telah diujikan pada remaja panti asuhan X di Yogyakarta. Peneliti melakukan modifikasi pada modul tersebut dengan menyesuaikan responden yaitu survivor bipolar. Adapun langkah-langkah inti dalam melakukan Pelatihan Berpikir Positif adalah sebagai berikut :

a. Mengenali diri

Responden dapat memahami kelebihan dan kekurangan dalam dirinya masing-masing

b. Afirmasi Diri

Responden dapat lebih memfokuskan pada kekuatan dan kelebihan yang ada dalam diri masing-masing peserta

c. Harapan yang Positif

Responden dapat lebih berkonsentrasi pada kesuksesan, memecahkan masalah, serta berani dalam menghadapi tantangan 
d. Kekuatan Berpikir Positif

Responden dapat memahami kekuatan berpikir positif dan mengerti contoh mengenai prasangka buruk

e. Pernyataan tidak menilai

Responden tidak terlalu mudah menilai negatif terhadap segala sesuatu hal

f. Penyesuian diri terhadap kenyataan

terlatih untuk menyesuaikan diri dari penyesalan dan menghindari menyalahkan diri sendiri

\section{Responden Penelitian}

Pengambilan subjek penelitian diambil berdasarkan metode random sampling. Dalam penelitian ini, subjek yang di teliti adalah ODB (orang dengan bipolar) merupakan anggota dari BCI (Bipolar Care Indonesia) simpul Jogja dan yang terdiagnosa bipolar minimal satu tahun. Jumlah subjek laki-laki yaitu dua orang, dan jumlah subjek perempuan yaitu delapan orang. Selanjutnya, subjek yang terlibat dalam penelitian ini ada satu orang yang terdiagnosa kurang dari dua tahu, tujuh orang yang terdiagnosa antara 2-7 tahun dan dua orang yang sudah terdiagnosa lebih dari empat tahun. Berikut adalah rata-rata lamanya subjek terdiagnosa gangguan bipolar :

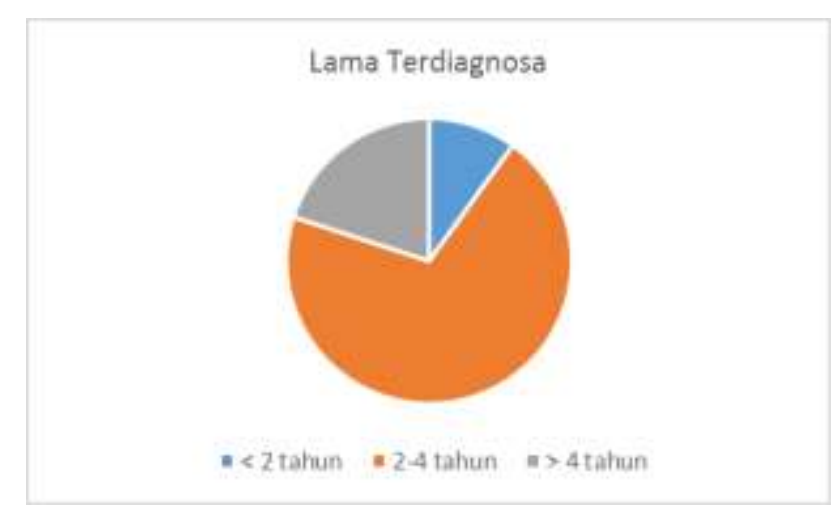

Gambar 1. Lama Terdiagnosa

\section{Metode Pengumpulan Data}

Metoda pengumpulan data dalam penelitian ini mengacu pada hasil wawancara dengan beberapa anggota Bipolar Care Indonesia. Data pendukung lain diperoleh dengan metode studi pustaka dan jurnal-jurnal ilmiah, serta 
literatur lain yang memuat bahasan yang berkaitan dengan penelitian ini. Adapun metoda pengumpulan data yang digunakan dalam penelitian ini adalah:

\section{a. Skala Penerimaan Diri}

Alat ukur yang digunakan dalam penelitian ini adalah skala Penerimaan Diri yang dimodifikasi dari skala penerimaan diri wanita yang mengalami kekerasan (Khoiryasdien \& Soeparno, 2015). Skala Penerimaan Diri akan diberikan kepada subjek sebelum diberikan program terapi untuk memperoleh gambaran awal yang konsisten terhadap kecencerungan tingkat penerimaan diri survivor bipolar. Kemudian, Skala Penerimaan Diri akan diberikan lagi setelah terapi untuk melihat perubahan tingkat penerimaan diri survivor bipolar

\section{b. Wawancara}

Wawancara dilakukan terhadap responden penelitian dengan panduan wawancara sebagai berikut :

1) Pertanyaan seputar data pribadi serta kehidupan sehari-hari serta data pemeriksaan responden sejak terdiagosa gangguan bipolar.

2) Pertanyaan yang berkaitan dengan etiologi, latar belakang keluarga, hubungan dengan orang tua, teman-teman, faktor peredisposisi, lingkungan/gaya hidup sehari - hari klien.

3) Pertanyaan seputar penerimaan diri responden setelah terdiagnosa gangguan bipolar serta permasalahan yang dihadapi.

\section{c. Observasi}

Aktivitas yang diamati dari responden penelitian selama pelatihan berpikir positif berlangsung antara lain:

1) Gejala yang nampak pada survivor bipolar yang belum lama terdiagnosa

2) Sikap responden dengan responden lain selama proses pelatihan berpikir positif

3) Respon responden selama diberikan pelatihan termasuk didalamnya kesulitan yang muncul pada proses pelatihan dan cara penanggulangannya. 


\section{Metode Pengolahan dan Analisis Data}

Pada penelitian ini terdapat dua teknik analisa yang akan digunakan, yaitu analisa kuantitatif dan analisa kualitatif. Teknik analisis yang digunakan dalam penelitian ini adalah statistik desriptif. Data kuantitatif yang diperoleh dalam penelitian klinis merupakan serangkaian data empiris hasil pengamatan terhadap sekelompok individu yang harus diolah, dianalisa, dan disimpulkan agar berguna dalam menggambarkan perilaku. Data kualitatif akan dianalisis menurut isinya (content analysis) atau disingkat analisis isi (Sugiyono, 2016). Data kualitatif yang dimaksud disini adalah data yang diperoleh dari wawancara, tugastugas yang dilakukan, maupun data yang diperoleh selama proses terapi selama tatap muka.

Analisis isi ini adalah teknik yang digunakan untuk menarik kesimpulan melalui usaha menemukan karakteristik pesan, serta dilakukan secara objektif dan sistematik (Bungin, 2011). Dengan analisis isi, peneliti menggunakan data yang ada untuk mengidentifikasi pola-pola yang nampak.

\section{Hasil}

Subjek adalah individu yang terdiagnosa gangguan Bipolar dan berdomosili di daerah Yogyakarta. Subjek juga merupakan anggota dari Bipolar Care Indonesia Simpul Jogja. Rentang usia subjek antara 22-43 tahun. Subjek penelitian sepuluh orang dengan jenis kelamin perempuan berjumlah delapan orang dan laki-laki berjumlah dua orang. Penelitian ini menggunakan skala penerimaan diri berdasarkan teori Johnson. Skala kuesioner ini berisi empat kategori jawaban yang memiliki nilai di setiap masing-masing jawaban, yaitu:

Tabel 2. Tabel Kategori Jawaban Skala Penerimaan Diri

\begin{tabular}{lll}
\hline Kategori & Deskripsi & Nilai \\
\hline STS & Sangat Tidak Sesuai & 1 \\
\hline TS & Tidak Sesuai & 2 \\
\hline S & Sesuai & 3 \\
\hline SS & Sangat Sesuai & 4 \\
\hline
\end{tabular}


Dalam penelitian ini, proses pengumpulan data akan dimulai dari dilakukannya pengukuran terhadap tingkatpenerimaan diri pada subjek penelitian sebanyak satu kali sebelum diberikan terapi (Pretest $\rightarrow$ Y1) dengan menggunakan skala penerimaan diri. Selanjutnya subjek penelitian akan mengikuti program Pelatihan Berpikir Positif. Setelah pelatihan selesai diberikan, selanjutnya akan dilakukan kembali pengukuran terhadap tingkat penerimaan diri pada subjek penelitian sebanyak satu kali (Posttest $\rightarrow$ Y2) dengan menggunakan skala penerimaan diri. Pengukuran ini dilakukan untuk melihat perubahan tingkat penerimaan diri subjek penelitian setelah mengikuti kegiatan pelatihan berpikir positif yang fungsinya guna membantu subjek untuk meningkatkan penerimaan diri yang dimiliki. Perubahan tingkat penerimaan diri pada subjek penelitian dapat dilihat dari skala penerimaan diri dimana hasil dari skala tersebut. Jika skor yang didapatkan semakin kecil, maka menunjukan bahwa penerimaan diri mereka rendah. Akan tetapi jika skor penerimaan diri yang didapatkan tinggi maka penerimaan diri subjek juga tinggi. Dengan kata lain subjek bisa menerima kondisinya sebagai seorang survivor bipolar. Selama proses pelaksanaan, salah satu subjek mengundurkan diri dan tidak bisa mengikuti pelatiha hingga selesai. Subjek hanya mengikuti pelatihan berpikir positif pada hari pertama sehingga subjek dianggap gugur dan tidak bisa memenuhi kriteria subek penelitian. Oleh karena itu

Berikut merupakan hasil skor pretest tingkat penerimaan diri subjek sebelum melakukan Pelatihan Penerimaan Diri.

Tabel 3. Tabel Kategori Jawaban Skala Penerimaan Diri

\begin{tabular}{ccc}
\hline No & Subyek & Skor \\
\hline 1 & $\mathrm{P}$ & 161 \\
\hline 2 & $\mathrm{D}$ & 149 \\
\hline 3 & $\mathrm{~F}$ & 146 \\
\hline 4 & $\mathrm{~V}$ & 157 \\
\hline 5 & $\mathrm{Y}$ & 149 \\
\hline 6 & $\mathrm{~S}$ & 154 \\
\hline 7 & $\mathrm{M}$ & 142 \\
\hline 8 & $\mathrm{H}$ & 152 \\
\hline 9 & $\mathrm{E}$ & 136 \\
\hline
\end{tabular}


Kemudian dibawah ini adalah hasil skor posttest tingkat penerimaan diri subjek penelitian sesudah melakukan Pelatihan Berpikir Positif.

Tabel 4. Tabel Kategori Jawaban Skala Penerimaan Diri

\begin{tabular}{ccc}
\hline No & Subyek & Skor \\
\hline 1 & $\mathrm{P}$ & 149 \\
\hline 2 & $\mathrm{D}$ & 152 \\
\hline 3 & $\mathrm{~F}$ & 154 \\
\hline 4 & $\mathrm{~V}$ & 159 \\
\hline 5 & $\mathrm{Y}$ & 152 \\
\hline 6 & $\mathrm{~S}$ & 149 \\
\hline 7 & $\mathrm{M}$ & 144 \\
\hline 8 & $\mathrm{H}$ & 150 \\
\hline 9 & $\mathrm{E}$ & 154 \\
\hline
\end{tabular}

Jika dilihat dari hasil skor pretest maupun posttest, maka terdapat peningkatan skor dari sebelum dan sesudah pelatihan. Berdasarkan nilai pre-post test menunjukan bahwa ada enam orang yang mengalami kenaikan skor penerimaan diri setelah pelatihan dan ada tiga orang yang mengalami penurunan. Hasil skor pelatihan dapat dilihat berdasarkan grafik berikut :

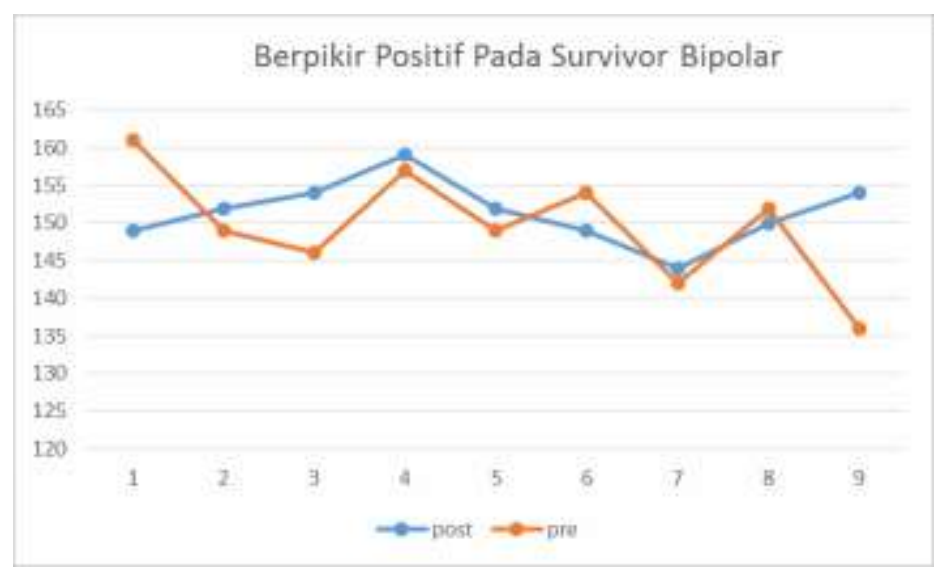

Gambar 2. Grafik hasil pelatihan berpikir positif

\section{Pembahasan}

Penelitian ini bertujuan untuk mengetahui apakah Pelatihan Berpikir Positir efektif untuk meningkatkan penerimaan diri pada survivor bipolar. Hipotesis penelitian yang dinyatakan diterima menunjukkan bahwa Pelatihan 
Berpikir Positif terbukti efektif untuk meningkatkan penerimaan diri pada survivor bipolar.

Di Yogyakarta sendiri, cukup banyak orang yang sudah terdiagnosis gangguan bipolar, hanya saja belum pernah dilakukan survey sehingga belum diketahui secara pasti jumlah ODB di Yogyakarta. Meskipun begitu, Yogyakarta mempunyai komunitas khusus untuk orang yang mengalami gangguan bipolar yaitu Bipolar Care Indonesia atau yang biasa disingkat dengan BCI simpul Jogja.

Berdasarkan hasil wawancara dengan beberapa ODB, saat seseorang terdiagnosis ODB tentu dia akan merasa shock dan sulit untuk mempercayainya karena bisa dikatakan bahwa gangguan bipolar akan menetap pada diri seseorang selama hidupnya, terkecuali ODB rajin melakukan psikofarmaka dan psikoterapi. Saat ODB sudah mau menerima dan melakukan pengobatan dengan baik, maka dosis obat pun bisa diturunkan,sedikit demi sedikit sesuai dengan kebutuhan pasien. Intensitas dalam melakukan Psikoterapi juga bisa dikurangi. Oleh karena itu, penelitian ini bertujuan untuk meningkatkan penerimaan diri adalah dengan memberikan Pelatihan Berpikir Positif.

Peneliti menggunakan modul pelatihan berpikir positif yang disusun oleh (Rufaida, 2018) dan dimodifikasi oleh peneliti dengan menyesuaikan responden yaitu survivor bipolar. Pelatihan berpikir positif ini mengacu pada aspek-aspek berpikir positif menurut Albrecht yang diintegrasikan dengan teori A-B-C Albert Ellis yang dikemas dalam bentuk sesi-sesi praktek Afirmasi Diri, Harapan yang Positif, Pernyataan yang Tidak Menilai serta Penyesuaian Diri terhadap Kenyataan. Pada tiap sesi praktek games tersebut akan dipraktekan teori A-B-C Ellis, sehingga survivor bipolar dapat mengalami sendiri secara langsung pikiran yang muncul dalam diri masing-masing indvidu atas terjadinya suatu peristiwa. Dampak tersebut antara lain, (A) yang dapat berdampak pada emosi serta perilaku individu (C). A adalah keberadaan suatu fakta, suatu peristiwa, tingkah laku atau sikap individu, $\mathrm{B}$ adalah keyakinan individu tentang $\mathrm{A}$, dan $\mathrm{C}$ yakni reaksi emosional (Corey, 2010).

Berdasarkan hasil penelitian, menunjukkan bahwa ada perbedaan skor penerimaan diri pada subjek penelitian pada saat dilakukan uji pretest dan posttes. 
Subjek dalam penelitian ini awalnya berjumlah 10 orang, akan tetapi satu orang mengundurkan diri karena dalam kondisi kurang stabil, sehingga subjek dianggap gugur dan tidak masuk dalam kriteria subjek penelitian. Berdasarkan sembilan orang yang mengikuti seluruh rangkaian pelatihan, tiga orang mengalami penurunan skor penerimaan diri. Meskipun begitu, berdasarkan hasil wawancara terhadap tiga orang subjek tersebut, mereka bisa merasakan manfaat dari pelatihan berpikir positif. Hanya saja, saat kondisi mengarah pada episode depresi subjek memang masih kesulitan untuk mengontrol pikiran negatif. Hal ini sesuai dengan yang disampaikan oleh (Nevid, 2007) dan (Muslim, 2013) bahwasanya saat penderita bipolar mengalami episode depresi maka seseorang cenderung akan kehilangan minat, menarik diri dari lingkungan dan selalu berpikir negatif tentang dirinya, seperti merasa diri tidak berguna, merasa diri buruk dan lain-lain. Selain karena adanya fase depresi, penerimaan diri juga didasarkan pada kondisi emosi yang tidak berat. Dalam kondisi ini, dapat dipahami bahwa kondisi ODB yang termasuk dalam gangguan jiwa berat juga sangat mempengaruhi penerimaan diri pada subjek. Hal ini sesuai dengan beberapa faktor-faktor yang dapat mempengaruhi penerimaan diri seseorang yakni pemahaman tentang diri sendiri, harapan yang realistis, tidak adanya gangguan emosional yang berat, pengaruh keberhasilan yang dialami, identifikasi dengan orang yang memiliki penyesuaian diri yang baik serta perspektif diri yang luas (Windarti, Wahyuni, \& Rosjidi, 2019)

Berpikir positif sendiri memiliki empat aspek, yaitu positive expectation (harapan positif), self affirmation (afirmasi diri), non judgement talking (pernyataan yang tidak menilai), dan reality adaptation atau penyesuaian diri (Machmudati \& Diana, 2017). Berdasarkan hasil intervensi, menunjukan bahwa enam orang subjek yang mengalami kenaikan skor pada pelatihan berpikir positif mengaku bahwa mereka bisa lebih optimis dalam menjalani hidup kedepan meskipun mereka terdiagnosa gangguan jiwa bipolar. Optimisme tersebut membuat subjek mempunyai gambaran dan rencana-rencana positif di masa depan nanti. Hal ini sesuai dengan yang disampaikan oleh (Caprara \& Steca, 2005) bahwasanya optimisme adalah evaluasi umum seseorang terhadap masa depan 
yang merefleksikan kepercayaan terhadap munculnya hal-hal yang baik dan berkurangnya hal-hal yang buruk.

Hal-hal lain yang menjadi output dari penelitian ini adalah seluruh subjek dapat mengetahui kelebihan dan kekurangan diri, dan yang terpenting adalah subjek meyakini bahwa individu tidak harus dicintai dan dihargai oleh individu lain untuk bisa merasa berharga. Saat subjek menyadari dan meyakini kekuatan atau kelebihan yang ada di dalam diri, subjek menjadi cenderung lebih percaya diri dalam menjalani kesehariannya (Perloff, 1997). Hal ini sangat penting dimiliki oleh seseorang yang mengalami bipolar karena ODB harus menyesuaikan diri dengan kenyataan. ODB harus bisa bersikap realistis termasuk saat menghadapi berbagai permasalahan. Sehingga saat kondisi diri sedang berada dalam fase depresi atau mania, ODB dapat mengukur diri sehingga tidak memperburuk kondisi diri, tetap bisa beradaptasi dan bisa tetap menjalani hidupnya dengan baik. Secara keseluruhan, dapat dikatakan bahwa pelatihan berpikir positif memberikan pengaruh pada subjek kearah yang lebih positif. Subjek dapat menerima kondisi yang mereka alami yaitu sebagai ODB (orang dengan bipolar) dan tetap memiliki optimisme untuk melanjutkan hidupnya menjadi lebih baik. Sesuai dengan Limbert (2004) bahwa berpikir positif mempunyai peran dapat membuat individu menerima situasi yang tengah dihadapi secara lebih positif.

\section{Kesimpulan Dan Saran}

\section{Kesimpulan}

Hasil penelitian menunjukkan Pelatihan Berpikir Positif untuk meningkatkan penerimaan diri pada survivor bipolar efektif untuk meningkatkan penerimaan diri ODB (Orang Dengan Bipolar). Hal ini ditunjukkan dengan peningkatan skor penerimaan diri pada subjek setelah diberikan Pelatihan Berpikir Positif.

Kemudian dari hasil analisa kualitatif, dapat disimpulkan bahwa pelatihan berpikir positif pada gangguan bipolar dapat meningkatkan penerimaan 
diri subjek sebagai seorang ODB (Orang Dengan Bipolar) dan meningkatkan optimisme ODB untuk bisa menjalani masa depannya dengan lebih baik.

\section{Saran}

Berikut ini terdapat saran-saran yang terkait dengan hasil dan pembahasan penelitain, yaitu:

1. Bagi subjek penelitian, menghindari kemungkinan terjadinya penurunan penerimaan diri maka keterampilan-keterampilan yang telah dipelajari selama sesi terapi agar terus diterapkan dalam kehidupan sehari-hari

2. Kepada pihak peneliti yang tertarik membahas penerimaan diri agar lebih memperhatikan faktor tipe kepribadian yang dimiliki subjek dan pola asuh yang dimiliki dari masing-masing subjek. Selain itu peneliti juga sebaiknya memperhatikan kondisi kestabilan emosi subjek.

3. Kepada pihak peneiliti berikutnya, sebaiknya memperhatikan faktor jenis kelamin agar hasil penelitian semakin spesifik karena dibedakan antara laki-laki dan perempuan.

\section{DAFTAR PUSTAKA}

Abdurahman, N. (n.d.). 2020, Penyakit Akibat Depresi Menajdi Peringkat Nomor Dua Dunia Artikel ini telah tayang di tribunjabar.id dengan judul 2020, Penyakit Akibat Depresi Menajdi Peringkat Nomor Dua Dunia, https://jabar.tribunnews.com/2017/04/08/2020-penyakit-akibat-depresi-m.

Retrieved from https://jabar.tribunnews.com/2017/04/08/2020-penyakitakibat-depresi-menajdi-peringkat-nomor-dua-dunia

Alwisol. (2014). Psikologi Kepribadian (Edisi Revisi). In UMM Press.

Bungin, B. (2011). Penelitian Kualitatif: Komunikasi, Ekonomi, Kebijakan Publik, Dan Ilmu Sosial Lainnya In Kencana. https://doi.org/10.1002/jcc.21776

Caprara, G. V., \& Steca, P. (2005). Affective and social self-regulatory efficacy beliefs as determinants of positive thinking and happiness. European Psychologist. https://doi.org/10.1027/1016-9040.10.4.275

Chatton, A. N. (2016). Ampuhnya Berpikir Positif. Yogyakarta: Soufa. 
Corey, G. (2010). Teori dan Praktek Konseling Psikoterapi. Bandung : PT Refika Aditama. https://doi.org/10.4324/9781315853178

Hurlock, E. (2014). Perkembangan Anak Edisi Keenam Jilid I. Jakarta. In Penerbit Erlangga. https://doi.org/10.1078/0944-2006-00091

Hurlock, E. B. (1991). Psikologi Perkembangan: Suatu Pendekatan Sepanjang Rentang Kehidupan (Edisi 5). Psikologi Perkembangan.

Indarini, N. (n.d.). Ketika Didiagnosis Gangguan Bipolar, Ini yang Perlu Dilakukan. Retrieved from https://health.detik.com/berita-detikhealth/d3438483/ketika-didiagnosis-gangguan-bipolar-ini-yang-perlu-dilakukan

Khoiryasdien, A. D., \& Soeparno, K. (2015). Pengaruh Terapi Pemaafan LaTahzan Dalam Meningkatkan Penerimaan Diri Istri Yang Mengalami Kekerasan Dalam Rumah Tangga. Jurnal Intervensi Psikologi (JIP). https://doi.org/10.20885/intrvensipsikologi.vol7.iss1.art2

Limbert, C. (2004). Psychological wellbieng and satisfaction amongst military personel on unaccompanied tours: the impact of perceived social support and coping strategies. Journal of Military Psychology, 16(1), 37-51.

Machmudati, A., \& Diana, R. R. (2017). Efektivitas Pelatihan Berpikir Positif untuk Menurunkan Kecemasan Mengerjakan Skripsi pada Mahasiswa. Jurnal Intervensi Psikologi https://doi.org/10.20885/intervensipsikologi.vol9.iss1.art8

Macleod, A. K., \& Moore, R. (2000). Positive thinking revisited: positive cognitions, well-being and mental health. Clinical Psychology \& Psychotherapy. https://doi.org/10.1002/(sici)1099-0879(200002)7:1<1::aidcpp228>3.0.co;2-s

Muslim, R. (2013). Gangguan depresi mayor. dalam: buku saku: diagnosis Gangguan jiwa,rujukan ringkas dari PPDGJ III dan DSM 5. In Arlington. https://doi.org/10.1176/appi.books.9780890425596.744053

Nevid, J. S. (2007). Psikologi Abnormal. Jurnal Kesehatan Jiwa. https://doi.org/10.1111/j.1533-8525.1976.tb01885.x

Perloff, R. (1997). Daniel Goleman's Emotional intelligence: Why it can matter more than IQ. The Psychologist-Manager Journal. https://doi.org/10.1037/h0095822

Quilliam, S. (Ed). (2007). Positive Thinking. (Terjemahan Beyamin Molan) Jakarta: Dian Rakyat. 
Rahmandani, A., \& Subandi, M. A. (2010). Pengaruh Terapi Pemaafan Dalam Meningkatkan Penerimaan Diri Penderita Kanker Payudara. Jurnal Intervensi Psikologi $(J I P)$. https://doi.org/10.20885/intervensipsikologi.vol2.iss2.art1

Rufaida, H. D. (2018). Pelatihan Berpikir Positif untuk Peningkatan Harga Diri Remaja Panti Asuhan Yatim Putri " $X$ " di Yogyakarta. Universitas Mercu Buana Yogyakarta.

Safira, F. (2014). Hubungan Antara Gangguan Bipolar Dengan Risiko Bunuh Diri Pada Pasien Rawat Inap Di Rumah Sakit Jiwa Daerah Sungai Bangkong Pontianak Tahun 2014. Implementation Science. https://doi.org/10.4324/9781315853178

Santoso, B. (2011). Skema dan Mekanisme Pelatihan Panduan Penyelenggaraan Pelatihan. Yogyakarta: Yayasan Terumbu Karang Indonesia.

Sugiyono, P. D. metode penelitian kuantitatif, kualitatif,dan R\&D. , Alfabeta, cv. (2016).

Windarti, Y., Wahyuni, N. S., \& Rosjidi, C. H. (2019). Tingkat Penerimaan Diri Wanita Usia Subur Yang Mengalami Infertil Di Salah Satu Rumah Sakit Swasta Di Ponorogo. Health Sciences Journal. https://doi.org/10.24269/hsj.v3i1.216 